\title{
The Oral Cannabis Poisoning of the Child (About 36 Cases)
}

\section{Ismaili G*, Jbabri A and Benjelloun Dakhama BS}

The pediatric medical emergencies department, Children's Hospital of Rabat, Morocco

\begin{abstract}
Background: The aim of this study was to describe cannabis poisoning of children.

Methods: 36 pediatrics patients with cannabis intoxication from January 2011to January 2013 reviewed retrospectively in the descriptive study.

Results: cannabis poisoning represent $8,5 \%$ of general intoxications hospitalized in our emergency unit, Children between 3 and 10 years old are the most exposed to poisoning (41\%) with male's predominance. The poisoning is accidental except for teenagers. Cardiovascular signs and neurological signs were commonly found. Two deaths were noted.

Conclusions: The purpose of this study was to assess about this new child's poisoning in our country and its danger.
\end{abstract}

Keywords: Cannabis poisoning; child

\section{Introduction}

Poisoning is a frequent cause of consultation and hospitalization in pediatrics medical emergencies. Oral cannabis intoxication is an uncommon cause. Even for nurslings the prognosis is usually favorable; it can lead to severe complications especially in the case of mass poisoning.

\section{Materials and Methods}

This is a retrospective descriptive study, in the Children's Hospital medical emergency department of Rabat in a period of 3 years. Its main purpose includes the epidemiology, the clinical aspects and the evolution of nurslings and children admitted in our department for oral cannabis poisoning.

\section{Results}

We identified 36 cases of cannabis intoxication. They represent 8 , $5 \%$ ofgeneral intoxications (except food poisoning ). The estimated age of poisoned patients is between 9 months and 15 years. Out of these patients 28 were males, 8 were females. Children between 3 and 10 years old are the most exposed to poisoning $(41 \%)$, followed by teens (36\%) then nurslings (23\%) (Figure1).

The poisoning is accidental for nurslings and children but voluntary for adolescents. $20 \%$ of the cases use cannabis alone and in $80 \%$ it is mixed with other ingredients. Our investigation revealed that the

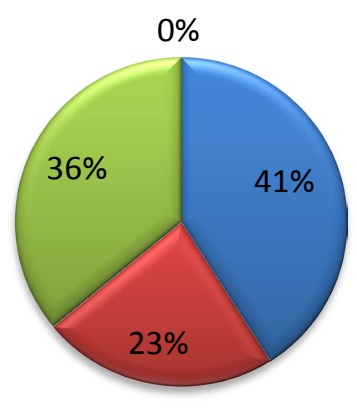

$\nabla$ age between

3 and 10

■nursling

$\square$ teens

Figure1: Distribution of patients according to Age. main cause of poisoning was the use of cannabis by a family member $(85 \%)$. However the remaining $15 \%$ are related to teenage influence during school years. The average consultation delay is 3 hours, the most common clinical symptoms are: cardiovascular signs (tachycardia , palpitations ), and neurological signs (confusion, headache...) All our patients do benefit of a minimum of 24 hours hospitalization with preconditioning, at the same time we contact the poison control center to report the cases and discuss the measures to take. Then a blood test associated with the evaluation of toxic in blood and urine is taken. Without forgetting to alert the judicial. The evolution is favorable in most cases (92\%).only one nursling was admitted to intensive care for altered case of consciousness with respiratory distress. two deaths were noted (Figure 2).

A psychiatric follow up has been suggested for all adolescents.

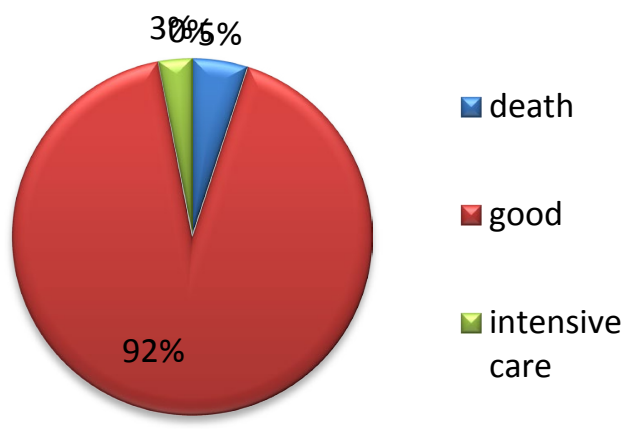

Figure 2: Immediate clinical evolution of patients.

*Corresponding author: Ismaili G, The pediatric medical emergencies department, Children's Hospital of Rabat, Morocco, Tel: 21261208180; E-mail: ismaili.ghizlane86@gmail.com

Received March 10, 2014; Accepted June 09, 2014; Published June 19, 2014

Citation: Ismaili G, Jbabri A, Benjelloun Dakhama BS (2014) The Oral Cannabis Poisoning of the Child (About 36 Cases). Chem Sci J 5: 086. doi: 10.4172/21503494.1000086

Copyright: @ 2014 Ismaili G, et al. This is an open-access article distributed under the terms of the Creative Commons Attribution License, which permits unrestricted use, distribution, and reproduction in any medium, provided the original author and source are credited. 
Citation: Ismaili G, Jbabri A, Benjelloun Dakhama BS (2014) The Oral Cannabis Poisoning of the Child (About 36 Cases). Chem Sci J 5: 086. doi: 10.4172/2150-3494.1000086

\section{Discussion}

The active ingredient of cannabis commonly used in Morocco is delta -9 -hydro- cannabinol tetra (THC), which comes from the leaves and flowers of Cannabis Sativa [1]. Gastrointestinal absorption of cannabis is 5 to $10 \%$ in comparison with the inhalation of marijuana's smoke (50\%). The symptomatology appears in $1 \mathrm{~h} 30$ to $3 \mathrm{~h}$ after the ingestion [2].

In our study, Parents mostly consult in a delay of $3 \mathrm{~h}$. The clinical signs are variable and depend on both the absorbed quantity and duration of exposure. They are most often neurological symptoms like agitation, somnolence, and ataxia or cardio respiratory signs like bradypnea and tachycardia. Also a conjunctival hyperemia, mydriasis and hypothermia can be found [3-5]. The evolution depends on the amount of ingested cannabis. The half-life of THC and its derivative is between 22 to 25 hours. However, according to some authors, it could be extended in case of massive poisoning, because of the active accumulation in fatty tissues, which helps detects cannabinoids in urine up to 12 days after ingestion [1,2]. Detection of poisoning is often evident for adolescents (clinical signs, suggestive context), it is less evident for infants and nurslings because signs of toxicity are not specific (hypotonia, crying, respiratory signs) and parents confess with difficulty because of the illicit nature of this drug [6-8]. The diagnosis is confirmed by the research of cannabinoids in the urine. This search can be done by immune fluorescence, polarization and immunoassay or radioimmunoassay [9]. For monitoring at least four hours are required if a patient ingest cannabis and should be continued for at least 24 hours if the child becomes symptomatic [10]. We keep under observation our entire patient for 24 hours. Treatment is essentially symptomatic. An admission in intensive care units is necessary for patients with neurological or respiratory disorders requiring mechanical ventilation [7].If the child is conscious, a gastric lavage may be proposed in the first hour after the ingestion. Some authors recommend the administration of activated charcoal as it would act on the liver enteric cycle of cannabis [11-14].The best treatment is the prevention and awareness of parents as well as children and teens about the danger of this drug that is wrongly considered safe [1]. In the case of young children, a warning authority must be performed [12]

\section{Conclusion}

Our study reveals an increasing type of poisoning, often underestimated especially in children, of which the clinical signs are atypical and where the diagnosis is mainly based on the interrogation and laboratory research of toxic. Cannabis toxicity is life-threatening for infants due to the respiratory and the neurological problems it can lead to. Moreover, in this case, could we consider it as a new form of domestic violence against the child?

\section{References}

1. Mollya C, Morya O, Bassetb T, Paturalc $\mathrm{H}$ (2012) Acute cannabis poisoning in a 10-month-old infant. Archives de Pediatrie 19: 729-732.

2. Spadari M, Glaizal M, Tichadou L (2009) Intoxications accidentelles par cannabis chez l'enfantexpe'rience du centre antipoison de Marseille. Press Med 38: 1563-7.

3. Gaulier JM, Tonnay V, Benkemoun P (2002) Intoxication cannabiqueaigue chez un enfant de dix mois. Arch Pediatr 9: 1112-3.

4. Croche Santander B, Alonso Salas MT, Loscertales Abril M (2011) Accidenta cannabis poisoning in children: report of four cases in a tertiary care center from southern Spain. Arch Argent Pediatr 109: 4-7.

5. Achour S, Rhalem N, Sefiani H (2009) Caracteristiques cliniques et therapeutiques des intoxications par le Cannabis données du Centre antipoison et de pharmacovigilance du Maroc. Rev Epidemiol Sante' Publique 5: S5.

6. Marcou A, Paon JC, Dufour D (2004) Intoxication cannabique chez un enfant de 11 mois. Press Med 33: 940.

7. Macnab A, Anderson E, Susak L (1989) Ingestion of cannabis: a cause of coma in children. Pediatr Emerg Care 5: 238-9.

8. Appelboam A, Oades PJ (2006) Coma due to cannabis toxicity in an infant. Eur J Emerg Med 13: 177-9.

9. Cone EJ, Johnson RE, Paul BD (1988) Marijuana-laced brownies: behaviora effects, physiologic effects, and urinalysis in humans following ingestion. J Anal Toxicol 12: 169-75

10. Lacroix J, Farrell CA, Gaudreault P (1992) Intoxication orale au cannabis chez septenfants. Reanim Urg 1: 906-9.

11. Velasco Arnaiz E, Trenchs Sainz de la Maza V, Curcoy Barcenilla Al (2010) ?Quie'n da positivo para cannabis en urgencias depediatrı'a? Anales de Pediatrı'a 72: 385-90.

12. Chung T, Colby SM, O'Leary TA (2003) Screening for cannabis use disorders in an adolescent emergency department sample. Drug Alcohol Dependence 70: 177-86.

13. Brissaud O, Chevret L, Claudet I (2006) Intoxication grave par me'dicaments et/ou substances illicites admise en re'animation : spe'-cificite's pe'diatriques. Reanimation 15: 405-11.

14. Garcl'a-Algar O, Papaseit E, Velasco M (2011) Consulta enurgencias de pediatrı'a por intoxicacio'n aguda por drogas deabuso. Anales de Pediatrı'a74 e1-9. 